\title{
Nutrient Administration and Resistance Training
}

\author{
Chad M. Kerksick, MS, CSCS*D, ATC, NSCA-CPT and Brian Leutholtz, PhD, FACSM \\ Exercise and Sport Nutrition Laboratory, Center for Exercise, Nutrition and Preventive Health \\ Research, Department of Health, Human Performance and Recreation, Baylor University. \\ Address correspondence to Chad_Kerksick@baylor.edu
}

Received March 15, 2005 /Accepted June 11, 2005/Published (online)

\begin{abstract}
Skeletal muscle tissue is tightly regulated throughout our bodies by balancing its synthesis and breakdown. Many factors are known to exist that cause profound changes on the overall status of skeletal muscle, some of which include exercise, nutrition, hormonal influences and disease. Muscle hypertrophy results when protein synthesis is greater than protein breakdown. Resistance training is a popular form of exercise that has been shown to increase muscular strength and muscular hypertrophy. In general, resistance training causes a stimulation of protein synthesis as well as an increase in protein breakdown, resulting in a negative balance of protein. Providing nutrients, specifically amino acids, helps to stimulate protein synthesis and improve the overall net balance of protein. Strategies to increase the concentration and availability of amino acids after resistance exercise are of great interest and have been shown to effectively increase overall protein synthesis. ${ }^{1-3}$ After exercise, providing carbohydrate has been shown to mildly stimulate protein synthesis while addition of free amino acids prior to and after exercise, specifically essential amino acids, causes a rapid pronounced increase in protein synthesis as well as protein balance. ${ }^{1,3}$ Evidence exists for a dose-response relationship of infused amino acids while no specific regimen exists for optimal dosing upon ingestion. Ingestion of whole or intact protein sources (e.g., protein powders, meal-replacements) has been shown to cause similar improvements in protein balance after resistance exercise when compared to free amino acid supplements. Future research should seek to determine optimal dosing of ingested intact amino acids in addition to identifying the cellular mechanistic machinery (e.g. transcriptional and translational mechanisms) for causing the increase in protein synthesis. Journal of the International Society of Sports Nutrition. 2(1):50-67, 2005.
\end{abstract}

\section{Key Words: sport nutrition, protein, timing, amino acids, latency, balance}

\section{INTRODUCTION}

The maintenance of skeletal muscle throughout our lifespan is of large importance. Skeletal muscle comprises approximately $40 \%$ of our total body weight and $50-75 \%$ of the total protein mass. While providing architectural support, ambulation, and maintenance of body posture are some of the primary functions of skeletal muscle protein, skeletal muscle also holds a primary role in the transport of amino acids throughout the body. Besides the inherent genetic influences, the balance of skeletal muscle can be influenced by a number of factors which include hormones (cortisol, IGF-1, growth hormone, testosterone, insulin, glucagon), disease state (AIDS, cancer cachexia, multiple sclerosis, sepsis, burn victims), exercise (aerobic/anaerobic, pre- vs. post-exercise), and nutritional state (fasting, post-prandial, starvation). From a clinical perspective, tissue wasting populations (e.g. AIDS, sepsis, etc.) largely 
lose skeletal muscle, which becomes problematic when considering an overall loss of $\geq 30 \%$ of the total muscle protein mass can result in impairment of normal respiration, weakening of the immune system and other rudimentary functions. The turnover of skeletal muscle proteins, primarily actin and myosin, makes up approximately one-third to one-half of the body's total protein turnover, depending on age, nutritional state and other factors. Additionally, this turnover of body protein has been reported to account for $15-25 \%$ of resting energy expenditure due to the fact that $1-2 \%$ of all skeletal muscle is turned over each day under normal, healthy conditions. The balance of body protein is maintained by regulating a tight balance between protein synthesis and breakdown which is controlled by many different cellular mechanisms of which include initiation of various transcription factors, translation initiation, and different proteolytic systems (e.g. lysosomal, calpain and ubiquitin proteolytic systems). Overall protein anabolism or growth occurs when the rate of protein synthesis is greater than protein breakdown. In normal, healthy adults, amino acids and protein are constantly taken up and released by the muscle, which results in an overall net release and balance of amino acids. Both of these components are constantly impacted by a number of physiological and pathophysiological conditions such as exercise, hormones, aging, disease, fasting, feeding, etc. In many diseases, protein synthesis is diminished and/or protein breakdown is up-regulated causing an overall negative protein balance. While this may be of benefit in the short-term by making available fuel substrates to combat the disease state, the prolonged negative balance is associated with significant dysfunction and morbidity. The need for optimal amino acid transport and metabolism to sustain physiological function in conjunction with the myriad of challenges that this system is faced with on a daily basis has made this topic one of supreme interest $^{4-6}$.

Physical activity in the form of exercise, specifically resistance exercise, is one means which results in an overall increase in protein balance, which ultimately results in an increase of protein accretion. Protein accretion has been attributed to a large number of factors, some of which include previous training status, exercise intensity, and quite notably nutrient consumption. While resistance training by itself can increase protein synthesis, recent research has largely indicated that the administration of exogenous nutrients is needed to make the overall balance of protein positive. ${ }^{7,8}$ Subsequently, a small portion of this review paper will be dedicated to providing an overview of the changes seen in muscle protein synthesis and muscle hypertrophy while resistance training. The remainder of this review will then summarize the findings and recommendations in regards to nutrient administration as well as the recommended timing and composition of these nutrients. Efforts will be made to highlight the pertinent findings involving these topics to assist the reader in practical application of this information.

\section{CHANGES IN AMINO ACID CONCENTRATION DURING EXERCISE}

During times of stress (e.g. disease, exercise, burns) amino acids are mobilized from the free amino acid pool in the body, which is located in the plasma and other cellular spaces. $5,9,10$ This pool has been found to represent approximately $2 \%$ of the total amino acids inside the body with over half of them in the form of skeletal muscle. Some but not all of these mobilized amino acids are used for protein synthesis while others are used for energy provision/ oxidation or substrates towards gluconeogenesis. Exercise has been shown to cause changes in both the free amino acid concentration in addition to changes in protein metabolism. ${ }^{11-13}$ Aerobic exercise 
has been shown to be responsible for changes in amino acid concentrations as well as overall changes in protein synthesis. $^{13,14}$ Furthermore, resistance exercise has been found to stimulate profound changes in amino acid concentration and protein synthesis, ${ }^{11,12,15}$ resulting in changes in overall muscle hypertrophy. ${ }^{16}$ Additionally, studies have also reported increases in the fractional synthesis rate of protein in trained swimmers after a combined resistance and endurance exercise bout. ${ }^{17}$ An overall increase in muscle hypertrophy is the result of a prolonged state in which muscle protein synthesis rates are higher than their respective muscle protein breakdown values. Changes in muscle hypertrophy is reported to be a slow process, largely due to the close association between protein synthesis and breakdown. ${ }^{12,15}$

\section{RESISTANCE EXERCISE AND MUSCLE PROTEIN SYNTHESIS}

Resistance training is associated with an increase in post-workout muscle protein synthesis. ${ }^{12,15,18}$ The type of resistance exercise does not appear to be influential as long as a sufficient "overload" stimulus is applied throughout the exercise bout. To illustrate this point, a rather large number of studies conducted by Wolfe, Tipton and colleagues have routinely used what would be considered a modest resistance exercise session with recreational and competitive athletes, but they have continually reported substantial changes in protein synthesis, breakdown and balance. ${ }^{3,12,19}$ Furthermore, eccentric-based exercise is widely known to induce pronounced changes in muscle damage, ${ }^{20,21}$ delayed onset muscle soreness (DOMS), and inflammation. ${ }^{22,23}$ However, there is little support that resistance exercise of this type is more effective at increasing protein synthesis when compared to more traditional (concentric) exercises. ${ }^{12}$

In addition to causing an immediate increase in muscle protein synthesis, resistance exercise is also responsible for promoting an attenuated increase of protein synthesis within muscle. ${ }^{12,18}$ MacDougall et al., ${ }^{18}$ used a single bout of resistance exercise in trained subjects and found that resistance exercise caused a rapid increase (within 2-4 $\mathrm{h}$ ) in protein synthesis and that this increase lasts for 24-36 h. ${ }^{11}$ Phillips and colleagues conducted a similar study with untrained subjects and reported that protein synthesis was still significantly increased by $34 \%$ after $48 \mathrm{~h}^{12}$ These studies help to illustrate both the acute and prolonged increases in protein synthesis that result after continual resistance training. This is an important consideration for those individuals who are highly trained and trying to maximize the anabolic environment inside their bodies to cause muscle growth, and also for older or less active individuals who only resistance train a few days per week to prevent muscle atrophy and associated decreases in muscle function.

With the widespread affirmation that resistance training causes both an acute as well as extended increase in muscle protein synthesis, recent studies and improved techniques have been able to more clearly determine which components of skeletal muscle protein have been responsible for the increase in muscle hypertrophy. ${ }^{24,25}$ Until these advancements, researchers have not been able to determine which component of skeletal muscle protein (i.e. sarcoplasmic, mitochondrial, myofilaments [actin and myosin]) is the most responsible for the reported increases in protein synthesis. Upon considering the role of actin and myosin with the contractile process and their overwhelming composition in skeletal muscle it only makes sense that their growth should be largely responsible for the changes in muscle hypertrophy and the force-generating capability of muscle as has been reported in regards to amino acid transport throughout the muscle. ${ }^{5}$ Recent studies have confirmed these assumptions that the hypertrophy and changes in forcegeneration potential are largely due to 
changes in myosin and actin as a result of resistance training. ${ }^{24,25}$

Lastly, another important consideration relative to the changes seen in muscle protein synthesis which has received attention lately is the impact of chronic or repeated training on the acute response to a single bout of resistance training. As individuals continually participate in a resistance training program the overall magnitude of responses seen in regards to protein synthesis and breakdown steadily decreases. Tipton and Rennie, in a recent review discussed this issue in greater detail. $^{6,26}$ Briefly, the impact of a continual resistance training program on muscle protein synthesis and breakdown has been purported to decrease the higher training status an individual achieves. ${ }^{15}$ This phenomenon is largely thought to be the same response the body has with any other acute stressor such as exercise which results in an up-regulation of both protein synthesis and protein breakdown as has been discussed throughout. As the exposure to this stimulus becomes more accustomed the magnitude of the response will diminish. To further illustrate, Phillips et al. compared an untrained group to a trained group while monitoring changes in fractional protein synthesis and breakdown in response to a single bout of explosive exercise. ${ }^{15}$ Untrained subjects in this cross-sectional study reported a $37 \pm 5 \%$ increase in fractional protein breakdown over and above that found in the trained group, in addition to also demonstrating a larger increase in fractional protein synthesis. Collectively, in response to continual resistance training the changes in protein synthesis and breakdown appear to be diminished while the acute response seems to be higher in magnitude.

While many factors can be attributed to the changes seen in overall muscle hypertrophy, changes in regards to the mechanistic machinery responsible for protein translation would appear to be at the forefront of these adaptations. While many advances have been made in our understanding of the factors that control protein synthesis during resistance exercise, our comprehension of these mechanistic factors is still lacking. Many researchers have begun to explore this area with some success. The work from Kimball and colleagues are largely responsible for our current understanding of the eukaryotic initiation factor family (EIF) and how their overall presence and phosphorylation state is related to downstream initiation of protein translation. While this topic is beyond the scope of this review, the interested reader is encouraged to explore the following articles. ${ }^{27-32}$

\section{RESISTANCE EXERCISE AND MUSCLE PROTEIN BREAKDOWN}

In general, resistance exercise has been shown to increase in muscle protein breakdown for up to $3 \mathrm{~h}$ after exercise. ${ }^{9,11,12}$ Depending on the type and intensity of exercise, protein breakdown is thought to increase more making the overall protein balance in a negative state. Biolo and colleagues used untrained individuals and determined the changes in both protein synthesis and breakdown after a single bout of resistance exercise. Compared to basal levels, protein synthesis was increased $108 \pm 18 \%$ and protein breakdown was increased $51 \pm 17 \%$ for $3 \mathrm{~h}$ after completion of the exercise session. ${ }^{11}$ Overall protein balance, however, was still found to be negative $3 \mathrm{~h}$ after the exercise bout. Two other studies used previously trained individuals and also determined the response of muscle protein synthesis and breakdown in response to a single bout of resistance training. ${ }^{9,} 12$ These studies also found an increase of protein breakdown rates for up to $3 \mathrm{~h}$ after completion of the exercise with one of the studies reporting an increase of $18 \%$ for up to $24 \mathrm{~h} .{ }^{12}$ It is important to note that all of these studies were conducted with subjects in the fasted state which might have made a difference in regards to the protein breakdown levels in addition to overall protein balance as will be discussed later. 
Previously, the impact of training status will also play a role in the overall length and magnitude of response in regards to observed changes in muscle protein balance and should not be forgotten, ${ }^{12,18}$ but results from these findings help to illustrate the changes seen in protein balance for both trained and untrained individuals after a single bout of resistance exercise. Many of the research studies illustrating findings associated with changes in protein metabolism during resistance training can be found in table 1 .

\section{NUTRIENT ADMINISTRATION AND TIMING CONSIDERATIONS}

For years athletes have been consuming protein-based or amino acid-based supplements. Many studies have provided evidence to support that supplementation of free-form amino acid or otherwise whole or intact forms of protein (e.g. soy, casein, whey, colostrum) can enhance training adaptations seen while resistance training. ${ }^{33-}$

37 While this strategy has been well accepted by most, some researchers still contend that nutritional needs are not changed, ${ }^{6,26,38,39}$ while others feel this strategy is beneficial. ${ }^{34,40}$ Many recommendations have been generated in this regard to better supply the resistance training athlete with specific information about the quantity and composition of nutrients, ${ }^{39,41}$ suggested timing of their consumption, ${ }^{40,42}$ and overall impact of consuming these supplements. ${ }^{7,43}$ In this regard, much research has been completed in an attempt to identify what types of nutrients in addition to the optimal timing of them causes the most favorable changes in protein balance while resistance training. Due to the oftentimes overlapping nature of research designs regarding nutrient provision the most relevant conclusions can sometimes be difficult to grasp.

Subsequently, an attempt will be made throughout this review to synthesize these findings to better facilitate understanding of the abundance of literature on this topic.
Many primary factors (i.e. amino acid availability, contractile activity, rest, disease, ${ }^{10}$ hormonal influences [e.g. insulin, ${ }^{44}$ cortisol, ${ }^{45}$ growth hormone, testosterone]) have been found to have an impact on the stimulation of protein synthesis. Throughout this paper, availability or delivery of protein/amino acids and contractile activity are the two factors which will be emphasized. ${ }^{46}$ One of the first studies conducted which provided evidence that protein balance and synthesis was largely impacted by protein and amino acid availability involved infusion of amino acids. Biolo and colleagues infused a mixed amino acid mixture ( $\sim 35-40 \mathrm{~g}$ amino acids for an average male [e.g. $\sim 70 \mathrm{~kg}$ ]) into six untrained normal men and studied them at rest and then for $3 \mathrm{~h}$ after a leg resistance exercise routine. Protein synthesis was increased at rest due to the increase in amino acid concentration by $141 \pm 45 \%$. A substantial increase in muscle protein synthesis $(291 \pm 42 \%)$ was found after exercise in addition to increasing overall amino acid transport after exercise (30$100 \%){ }^{47}$ To summarize, this study helps to provide conclusive evidence that not only does greatly enhancing the delivery of amino acids at rest increase protein balance and protein synthesis but that an interactive effect appears to occur during the postexercise period which resulted in an approximate 2 -fold increase in protein synthesis after exercise when amino acids are readily available. ${ }^{47}$

\section{AMINO ACID AVAILABILITY AND PROTEIN SYNTHESIS}

While infusion of amino acids is extremely effective at enhancing the body's ability to increase protein synthesis it is not a practical means of delivery for most athletes and individuals interested in enhancing muscle hypertrophy or maintaining their skeletal muscle mass. A study by Tipton and colleagues was performed in hopes of determining if the impact of ingesting $1 \mathrm{~L}$ amino acid solutions (the most common 
Table 1: Summary of literature pertaining to protein metabolism response to resistance exercise

\begin{tabular}{|c|c|c|c|c|}
\hline $\begin{array}{l}\text { AUTHORS/ } \\
\text { REFERENCE }\end{array}$ & SUBJECTS & TYPE OF EXERCISE & SAMPLES & MAJOR OUTCOMES \\
\hline $\begin{array}{l}\text { Biolo et al. } \\
1995^{49}\end{array}$ & $\begin{array}{l}10(9 \mathrm{M}, 1 \mathrm{~F}) \text { healthy } \\
\text { volunteers }(19-52 \mathrm{yrs})\end{array}$ & NONE & $\begin{array}{l}\text { - A/V blood samples } \\
\text { - Muscle biopsies }\end{array}$ & $\begin{array}{l}\text { - AA infusion can validly quantify many important aspects of PRO } \\
\text { synthesis, breakdown and AA transport. }\end{array}$ \\
\hline $\begin{array}{l}\text { Biolo et al. } \\
1995^{11}\end{array}$ & $\begin{array}{l}5 \mathrm{M} \text { young }(24 \pm 2 \mathrm{yrs}) \\
\text { healthy males }\end{array}$ & $\begin{array}{l}\text { - Leg Press }(5 \times 10 \text { reps @ } 75 \% \\
1 \text { RM) } \\
\text { - Squat, leg curls/ext. ( } 4 \times 8 \text { reps } \\
\text { @ } 75 \% 1 \text { RM }\end{array}$ & $\begin{array}{l}\text { - PRO synthesis, PRO breakdown and } \\
\text { AA transport were determined at rest } \\
\text { and } 3 \mathrm{~h} \text { post-ex. }\end{array}$ & $\begin{array}{l}\text { - PRO synthesis and PRO breakdown are increased after resistance } \\
\text { exercise } \\
\text { - Post-ex. increase of AA transport may contribute to PRO synthesis }\end{array}$ \\
\hline $\begin{array}{l}\text { Tipton et al. } \\
1996^{17}\end{array}$ & $\begin{array}{l}7 \text { collegiate female } \\
\text { swimmers }\end{array}$ & $\begin{array}{l}\text { Four conditions: } \\
\text { - Resting (R) } \\
\text { - Intense swimming (S) } \\
\text { - Resistance ex. (RE) } \\
\text { - Swim + resistance ex. (SRE) }\end{array}$ & $\begin{array}{l}-5 \mathrm{~h} \text { testing period } \\
-4 \text { blood samples at } 4 \mathrm{~h} \text { and } 5 \mathrm{~h} \text { post- } \\
\text { ex. } \\
-2 \text { biopsies at } 1 \mathrm{~h} \text { and } 5 \mathrm{~h} \text { post-ex. }\end{array}$ & $\begin{array}{l}\text { - No difference in PRO breakdown for all conditions } \\
\text { - PRO synthesis increased after SRE vs. R } \\
\text { - Combined SRE increases PRO synthesis above resting levels in } \\
\text { female swimmers. }\end{array}$ \\
\hline $\begin{array}{l}\text { Phillips et al. } \\
1997^{12}\end{array}$ & $\begin{array}{l}8(4 \mathrm{M}, 4 \mathrm{~F}) \text { untrained } \\
\text { individuals }\end{array}$ & $\begin{array}{l}\text { - } 8 \text { x } 8 \text { concentric or eccentric } \\
\text { reps @ } 80 \% 1 \mathrm{RM}\end{array}$ & $\begin{array}{l}-\mathrm{A} / \mathrm{V} \text { blood at } 120,180,210,240,260 \text {, } \\
280 \text { and } 300 \text { min. } \\
\text { - Biopsies were taken at } 120,280 \text { and } \\
300 \text { min. }\end{array}$ & $\begin{array}{l}\text { - Increased synthesis rate at all time points ( } 3 \mathrm{~h}: 112 \%, 24 \mathrm{~h}: 65 \% \text {, } \\
48 \mathrm{~h}: 34 \%) \text {. } \\
\text { - Increased breakdown rate at } 3 \mathrm{~h}(31 \%) \text { and } 24 \mathrm{~h}(18 \%) \text {, but no diff. } \\
\text { at } 48 \mathrm{~h} \text {. } \\
\text { - Resistance exercise resulted in increases in protein balance that } \\
\text { persisted for up to } 48 \mathrm{~h} \text { and is independent of type of muscle } \\
\text { contractions. }\end{array}$ \\
\hline $\begin{array}{l}\text { Phillips et al. } \\
1999^{15}\end{array}$ & $\begin{array}{l}\text { Trained subjects (6) vs. } \\
\text { untrained subjects (6) }\end{array}$ & $\begin{array}{l}-10 \times 8 \text { eccentric reps } @ 120 \% \\
1 \mathrm{RM} \\
\text { - One leg exercised while other } \\
\text { was control }\end{array}$ & $\begin{array}{l}\text { - Femoral A/V blood samples } \\
\text { - Femoral muscle biopsies }\end{array}$ & $\begin{array}{l}\text { - Exercise increased both PRO synthesis and breakdown } \\
\text { - Training status diminishes the response of PRO synthesis and } \\
\text { breakdown }\end{array}$ \\
\hline $\begin{array}{l}\text { Hasten et al. } \\
2000^{24}\end{array}$ & $\begin{array}{l}7 \text { healthy young }(23-32 y) \\
\text { and } 7 \text { elder }(78-84 y) \\
\text { subjects }\end{array}$ & $\begin{array}{l}2 \text { week weight lifting program } \\
(3 \times 8-12 \text { reps @60-90\% } \\
1 \mathrm{RM})\end{array}$ & $\begin{array}{l}14 \mathrm{~h} \text { infusion to determine } \\
\text { incorporation of protein into vastus } \\
\text { lateralis }\end{array}$ & $\begin{array}{l}\text { - MHC and mixed protein after training increased in young }(88 \% \\
\text { and } 121 \%) \text { and older ( } 105 \text { and } 182 \%) \text { compared to baseline } \\
\text { - Older people retain capacity to increase MHC }\end{array}$ \\
\hline $\begin{array}{l}\text { Phillips et al. } \\
2002^{19}\end{array}$ & $\begin{array}{l}19 \text { young }(23.7 \pm 3.2 \mathrm{yrs}) \\
\text { untrained, healthy, male } \\
\text { subjects }\end{array}$ & $\begin{array}{l}-8 \text { week RE program } \\
(6 \mathrm{~d} / \text { week) } \\
\text { - During testing, one leg acted } \\
\text { as control }\end{array}$ & $\begin{array}{l}\text { - A/V blood samples and muscle } \\
\text { biopsies after acute, initial bouts of } \\
\text { RE and after } 6 \text { weeks of training }\end{array}$ & $\begin{array}{l}\text { - RE increases PRO balance in both legs but more so in exercised } \\
\text { leg } \\
\text { - Regular training attenuates increase in PRO synthesis }\end{array}$ \\
\hline $\begin{array}{l}\text { Pitkanen et al. } \\
2003^{9}\end{array}$ & $\begin{array}{l}12 \text { healthy, physically } \\
\text { active males }\end{array}$ & $\begin{array}{l}-50 \text { min. bout of lower-body } \\
\text { RE } \\
-3 \times 10 \text { reps@ @ 80\% 1RM w/1- } \\
1.5 \text { min. rest }\end{array}$ & $\begin{array}{l}\text { - A/V blood samples were provided } \\
\text { throughout entire } 5 \mathrm{~h} \text { protocol } \\
\text { - Biopsies were provided } 1 \mathrm{~h} \text { post-ex. } \\
\text { and } 3.5 \mathrm{~h} \text { post-ex. }\end{array}$ & $\begin{array}{l}\text { - Protein net balance is negative and similar between groups } \\
\text { - RES induces an increase in MPS and breakdown at } 195 \mathrm{~min} \text {. but } \\
\text { not by } 60 \mathrm{~min} \text {. post-ex. }\end{array}$ \\
\hline $\begin{array}{l}\text { Sheffield-Moore } \\
\text { et al. } 2004^{14}\end{array}$ & $\begin{array}{l}-6 \text { older } M \\
(69 \pm 1 \text { yrs }) \\
-6 \text { younger M }(29 \pm 2 \text { yrs })\end{array}$ & $\begin{array}{l}\text { - } 45 \text { min. treadmill walking @ } \\
\sim 40 \% \text { peak } \mathrm{VO}_{2}\end{array}$ & $\begin{array}{l}\text { - Femoral biopsies and } \mathrm{A} / \mathrm{V} \text { blood } \\
\text { samples at }-10,60 \text { and } 180 \text { min. post- } \\
\text { ex. }\end{array}$ & $\begin{array}{l}\text { - Protein synthesis and breakdown increased in both groups after } \\
\text { exercise } \\
\text { - Older individuals had increased protein breakdown compared to } \\
\text { younger individuals }\end{array}$ \\
\hline $\begin{array}{l}\text { Durham et al. } \\
2004^{64}\end{array}$ & $\begin{array}{l}7(5 \mathrm{M}, 2 \mathrm{~F}) \text { were studied at } \\
\text { rest and after exercise }\end{array}$ & $\begin{array}{l}\text { - Leg press }(8 \times 10 \text { reps } @ 75 \% \\
1 \mathrm{RM}) \text { and Leg ext. }(8 \times 8 \text { reps } \\
\text { (a) } 80 \% 1 \mathrm{RM})\end{array}$ & $\begin{array}{l}\text { - Femoral A/V blood and biopsies were } \\
\text { obtained at rest and immediately after } \\
\text { exercise. }\end{array}$ & $\begin{array}{l}\text { - Lower body RE increases glucose uptake and lactate release } \\
\text { - PRO synthesis is not elevated during a bout of RE }\end{array}$ \\
\hline
\end{tabular}


form of amino acid and/or protein supplementation) of different compositions would result in similar changes as that found after infusion of the amino acids. ${ }^{2}$ All subjects were tested three times in random order while ingesting either a placebo drink, a $40 \mathrm{~g}$ mixed amino acid (MAA) solution (21.4 $\mathrm{g}$ essential amino acid [EAA] $+18.6 \mathrm{~g}$ nonessential amino acid [NEAA]), or a $40 \mathrm{~g}$ EAA solution. Upon completion of the exercise bout, subjects rested for $45 \mathrm{~min}$ prior to beginning consumption of their solution over a period of $3 \mathrm{~h}$. Subjects then ingested approximately $4-5$ ounces $(\sim 100-150 \mathrm{~mL})$ every $15 \mathrm{~min}$ to ensure a constant delivery of the amino acids. When consuming the placebo solution, net protein balance was found to be negative overall, while ingestion of both amino acid solutions resulted in a net positive protein balance, primarily through an increase in protein synthesis. Net protein balance was found to be similar between the MAA and EAA solution leading the authors to speculate that ingestion of non-essential amino acids may not be necessary to maximally stimulate protein synthesis after resistance exercise. ${ }^{2}$ The authors also concluded that ingestion of amino acids resulted in similar stimulation of protein synthesis when compared to infusion of the amino acids. ${ }^{2,47}$ This latest study is quite valuable in its findings due to the 'real-world' practicality in which the subjects were asked to train and consume their respective supplemental solution. The combined findings from these two studies provide conclusive evidence that availability of amino acids to the exercising skeletal muscle in the post-prandial state results in large but similar changes in protein synthesis and overall protein balance. Additionally, the authors also suggested that ingestion of EAA may be all that is necessary to maximally stimulate protein kinetics after resistance exercise.

In an attempt to further explore the role that NEAA plays in initiating protein synthesis after a single bout of resistance exercise. In the first study, $6 \mathrm{~g}$ of EAAs and $35 \mathrm{~g}$ of carbohydrate $(\mathrm{EAA}+\mathrm{CHO})$ or a placebo was given to six subjects after completion of a resistance training exercise bout. ${ }^{3}$ The carbohydrate addition was made in an effort to maximize insulin secretion and further promote a positive protein balance as was found in a previous studies where local hyperinsulinemia stimulated muscle protein synthesis and/or prevented protein breakdown. ${ }^{44,48}$ At either $1 \mathrm{~h}$ or $3 \mathrm{~h}$ after conclusion of the exercise bout, the EAA $+\mathrm{CHO}$ solution was ingested, which resulted in similar increases in both protein balance and protein synthesis with no change in protein breakdown. The authors concluded that ingestion of the EAA $+\mathrm{CHO}$ solution either $1 \mathrm{~h}$ or $3 \mathrm{~h}$ after the exercise bout resulted in an approximate $400 \%$ increase in protein synthesis when compared to resting values. Consequently, the results from this study were one of the first to truly illustrate the possible benefit that may be derived from providing specific nutrients at designated time points relative to an acute bout of resistance training, while utilizing widely accepted methods, ${ }^{49,50}$ to identify amino acid and protein change in skeletal muscle. Collectively, information from this study suggest that oral ingestion of an amino acid solution, after a single bout of resistance exercise, containing anywhere from $6-40 \mathrm{~g}$ of predominantly EAA with or without carbohydrate will profoundly cause increases in protein synthesis and overall protein balance, providing additional evidence that NEAA may not be needed to stimulate protein synthesis. ${ }^{1,2,51}$ However, due to the action of the hormone of insulin, the addition of carbohydrate to this relatively low level of amino acids (6 g) could have possibly interacted with the amino acids in the postexercise environment to cause an even further increase in protein synthesis.

\section{INDEPENDENT IMPACT OF CARBOHYDRATE AND PROTEIN ON PROTEIN SYNTHESIS}

To determine the independent impact of carbohydrate and amino acid administration 1 $\mathrm{h}$ after an acute bout of resistance exercise, 
two studies were recently completed by Borsheim. In her first study, two groups of eight subjects ingested either a placebo or a $100 \mathrm{~g} \mathrm{CHO}$ solution $1 \mathrm{~h}$ after completing a standard resistance training exercise bout. Overall net protein balance was found to be negative after exercise while the administration of carbohydrate improved the net balance, but the overall balance was still negative. ${ }^{52}$ Furthermore, the responsiveness of this modest improvement took almost $3 \mathrm{~h}$ post-exercise while comparative studies using amino acids have illustrated much faster improvements in protein balance. ${ }^{1,51}$ While administration of carbohydrate post-exercise does marginally improve net muscle protein balance after resistance training, it is not the best option. In her second study, to determine the independent effect of a small dose $(6 \mathrm{~g})$ of EAA on the protein synthesis as well as the contribution of NEAA to an acute bout of resistance training, Borsheim et al. ${ }^{1}$ divided six subjects into two groups and each group ingested two equal doses of $6 \mathrm{~g}$ EAA or $3 \mathrm{~g}$ $\mathrm{EAA}+3 \mathrm{~g}$ NEAA at $1 \mathrm{~h}$ and $2 \mathrm{~h}$ after exercise. Net protein balance in this study was increased in both groups with overall protein balance two times higher after consumption of $12 \mathrm{~g}$ EAA when compared to the combined $6 \mathrm{~g}$ EAA +6 g NEAA. ${ }^{1}$ These results were also supported by the findings of Miller et al. after a $6 \mathrm{~g}$ dose of mixed amino acid and $35 \mathrm{~g}$ of carbohydrate. ${ }^{53}$ These findings and other studies have led to the conclusion that NEAA provide no additional contribution towards stimulation of muscle protein synthesis beyond that seen in EAA., 54 Additionally, EAA were able to significantly stimulate protein synthesis to a similar degree as previously conducted studies that used a combination of EAA + $\mathrm{CHO}^{51}$ or with amino acids alone with a dosage much lower $(6 \mathrm{~g})$ than that typically consumed by resistance trained athletes $(20-$ $50 \mathrm{~g}){ }^{53}$ To effectively summarize the findings from these two studies, ingesting carbohydrate alone after resistance exercise can improve overall protein balance but the findings are marginal. However, a small dose of EAA after resistance exercise has been found to stimulate similar changes in protein synthesis and protein balance compared to studies that used much larger doses of NEAA or EAA, with carbohydrate or without carbohydrate. Many of the studies illustrating changes in protein metabolism relative to exercise, nutrient timing and composition can be found in table 2 .

\section{NUTRIENT TIMING: BEFORE OR AFTER EXERCISE?}

Substantial evidence currently exists in support of the beneficial changes seen in muscle protein synthesis and protein balance if different nutrients are consumed after completion of an exercise bout. ${ }^{1,2,17,51,52,55}$ What remains to be agreed upon is the exact timing and composition of the ingested nutrients. A study providing a large bolus of carbohydrate $1 \mathrm{~h}$ after exercise resulted in marginal improvements in protein synthesis but still showed a net negative protein balance. ${ }^{52}$ Furthermore a series of studies, ${ }^{1,2}$, ${ }^{51}$ using small doses $(6-12 \mathrm{~g})$ of both essential and non-essential amino acids given $1 \mathrm{~h}$ after similar acute bouts of resistance training identified substantial but similar increases in protein synthesis resulting in a positive net protein balance. Also, a study by Esmark on elderly males after 12 weeks of resistance training found that when subjects ingested a mixed nutrient solution immediately after their workout as opposed to $2 \mathrm{~h}$ after they completed their workout, greater increases in muscle mass (determined by MRI) and strength, ${ }^{55}$ were reported, which supported other previous findings. ${ }^{56}$

Additionally, adding carbohydrate, further increases protein synthesis. ${ }^{3}$ Figure 1 is provided below to illustrate the reported changes seen with protein synthesis, protein breakdown and protein balance with differing combinations of exercise and nutrition.

Consequently, one fundamental question regarding nutrient timing has remained, "Before or After Exercise?" 
Table 2: Summary of Relevant Literature Pertaining to Nutrient Timing and Exercise

\begin{tabular}{|c|c|c|c|c|c|c|}
\hline $\begin{array}{c}\text { AUTHORS/ } \\
\text { REFERENCE }\end{array}$ & SUBJECTS & $\begin{array}{c}\text { SUPPLEMENT/ } \\
\text { DOSAGE }\end{array}$ & $\begin{array}{c}\text { TIME OF } \\
\text { ADMINISTRATION }\end{array}$ & TYPE OF EX. & SAMPLES & MAJOR OUTCOMES \\
\hline $\begin{array}{l}\text { Biolo et al. } \\
1997^{47}\end{array}$ & 6 untrained males & $\begin{array}{l}\text { - Infusion of } \\
\text { balanced AA } \\
\text { mixture } \\
\left(0.15 \mathrm{~g}^{-\mathrm{kg}^{-1}} \cdot \mathrm{h}^{-1}\right. \\
\text { for } 3 \mathrm{~h})\end{array}$ & $\begin{array}{l}\text { Two conditions: } \\
\text { - REST } \\
\text { - Post-ex. }\end{array}$ & $\begin{array}{l}\text { - Leg resistance } \\
\text { exercise routine }\end{array}$ & $\begin{array}{l}\text { - Muscle biopsies } \\
\text { - Arteriovenous } \\
\text { blood samples for } \\
3 \mathrm{~h} \text { post-ex. }\end{array}$ & $\begin{array}{l}\text { - PRO synthesis post-ex. > rest } \\
\text { - AA transport increased } 30-100 \% \text { post-ex. compared } \\
\text { to rest- PRO intake immediately post-ex. may be } \\
\text { more anabolic than other times }\end{array}$ \\
\hline $\begin{array}{l}\text { Kobayashi et al. } \\
2003^{30}\end{array}$ & $\begin{array}{l}10 \text { normal } \\
\text { Yorkshire swine }\end{array}$ & $\begin{array}{l}\text { Continuous } \\
\text { infusion of a } \\
\text { mixed AA } \\
\text { solution } \\
\end{array}$ & $\begin{array}{l}\text { Infusion began } 2 \mathrm{~h} \text { into } \\
\text { dialysis and for } \\
\text { remaining } 2 \mathrm{~h}\end{array}$ & NONE & $\begin{array}{l}\text { - A/V samples and } \\
\text { biopsies were } \\
\text { taken throughout } \\
\text { entire protocol. } \\
\end{array}$ & $\begin{array}{l}\text { - Signal to change }[\mathrm{AA}] \text { was plasma }[\mathrm{AA}] \\
\text { - Decrease in PRO synthesis led to decrease in eIF2B } \\
\text { activation } \\
\text { - Intramuscular }[\mathrm{AA}] \text { did not change }\end{array}$ \\
\hline Bohe et al. $2003^{59}$ & $\begin{array}{l}-21 \text { healthy } \\
\text { subjects }(11 \mathrm{M}, \\
10 \mathrm{~F}) \\
-29 \pm 2 \text { yrs }\end{array}$ & $\begin{array}{l}\text { - Mixed AA } \\
\text { infusion at } \\
\text { varying rates } \\
(44-261 \mathrm{mg} \\
\left.\mathrm{AA} \cdot \mathrm{kg}^{-1} \cdot \mathrm{h}^{-1}\right)\end{array}$ & $\begin{array}{l}\text { Study attempted to } \\
\text { determine any dose- } \\
\text { response relationship } \\
\text { to PRO synthesis }\end{array}$ & NONE & $\begin{array}{l}\text { - A/V blood samples } \\
\text { pre-infusion and } \\
\text { for next } 6.5 \mathrm{~h} \\
-4 \text { biopsies at } 30 \\
180,240 \text { and } 390 \\
\text { min. }\end{array}$ & $\begin{array}{l}\text { - Myofibrillar, sarcoplasmic, and mitochondrial PRO } \\
\text { synthesis was similar } \\
\text { - PRO synthesis is regulated by extracellular [EAA] } \\
\text { and becomes saturated at high concentrations. } \\
\text { - A dose-dependent relationship exists between [AA] } \\
\text { and PRO synthesis. }\end{array}$ \\
\hline Bohe et al. $2001^{58}$ & $\begin{array}{l}6(5 \mathrm{M}, 1 \mathrm{~F}) \\
\text { normal, healthy } \\
\text { adults }\end{array}$ & $\begin{array}{l}\text { - Infusion }(162 \\
\left.\mathrm{mg} \cdot \mathrm{kg}^{-1} \cdot \mathrm{h}^{-1}\right) \text { of } \\
\text { mixed AA }\end{array}$ & $\begin{array}{l}\text { 6h infusion period at } \\
\text { constant rate }\end{array}$ & NONE & $\begin{array}{l}\text { - A/V blood samples } \\
\text { over } 9 \mathrm{~h} \\
\text { - Muscle biopsies to } \\
\text { determine AA } \\
\text { incorporation } \\
\end{array}$ & $\begin{array}{l}\text { - PRO synthesis increase } \sim 2.8 \mathrm{x} \text { basal value within } 2 \\
\mathrm{~h} \text { of infusion } \\
\text { - PRO synthesis then declined rapidly } \\
\text { - AA availability may be limited by transport of AA } \\
\text { into muscle }\end{array}$ \\
\hline $\begin{array}{l}\text { Paddon-Jones et } \\
\text { al. } 2003^{45}\end{array}$ & $\begin{array}{l}12 \text { healthy male } \\
\text { and females }\end{array}$ & $\begin{array}{l}\text { Two conditions: } \\
\text { - Saline infusion } \\
+15 \mathrm{~g} \text { EAA } \\
\text { solution } \\
\text { - } 27 \mathrm{~h} \text { cortisol } \\
\text { infusion }+15 \mathrm{~g} \\
\text { EAA solution }\end{array}$ & $\begin{array}{l}\text { - Measurements were } \\
\text { taken pre- and post- } \\
\text { consumption of EAA } \\
\text { solution. }\end{array}$ & NONE & $\begin{array}{l}\text { - A/V blood before } \\
\text { and after EAA } \\
\text { ingestion. } \\
\text { - } 3 \text { biopsies were } \\
\text { taken (pre-/post- } \\
\text { infusion, } \\
\text { supplement } \\
\text { consumption) }\end{array}$ & $\begin{array}{l}\text { - Cortisol increased arterial, venous and muscle } \\
\text { intracellular AA concentrations. } \\
\text { - EAAs improved muscle protein anabolism during } \\
\text { acute hypercortisolemia and may help minimize } \\
\text { muscle loss following debilitating injury. }\end{array}$ \\
\hline $\begin{array}{l}\text { Levenhagen et al. } \\
2002^{65}\end{array}$ & $\begin{array}{l}5 \mathrm{M}, 5 \mathrm{~F} \text { tested } 3 \mathrm{x} \\
\text { with } 4 \text { week } \\
\text { wash-out }\end{array}$ & $\begin{array}{l}\text { Oral doses of: } \\
\text { - Placebo (P) } \\
\text { - } 8 \mathrm{~g} \text { CHO }+3 \mathrm{~g} \text { fat } \\
\text { (SUPP) } \\
\text { - } 8 \mathrm{~g} \text { CHO }+3 \mathrm{~g} \text { fat } \\
\text { + } 10 \mathrm{~g} \text { PRO } \\
\text { (SUPP+PRO) } \\
\end{array}$ & $\begin{array}{l}\text { Immediately after } \\
\text { exercise }\end{array}$ & $\begin{array}{l}\text { 60-min. cycling } \\
@ 60 \% \max \\
\mathrm{VO}_{2} \text { and } 180 \\
\text { min recovery } \\
\text { period. }\end{array}$ & $\begin{array}{l}\text { - Blood every } 15 \\
\text { min. before ex. } \\
\text { - Arterial and venous } \\
\text { blood every } 30 \\
\text { min. post-ex. for } \\
180 \text { min. }\end{array}$ & $\begin{array}{l}\text { - In compared to NO or SUPP, SUPP + PRO resulted } \\
\text { in a net uptake of EAA and increase in leg and } \\
\text { whole-body protein synthesis } \\
\text { - AA are more important than energy for post-ex. } \\
\text { repair and growth. }\end{array}$ \\
\hline
\end{tabular}




\begin{tabular}{|c|c|c|c|c|c|c|}
\hline $\begin{array}{l}\text { Levenhagen et al. } \\
2001^{56}\end{array}$ & $5 \mathrm{M}, 5 \mathrm{~F}$ & $\begin{array}{c}10 \mathrm{~g} \text { PRO }+8 g \\
\mathrm{CHO}+3 \mathrm{~g} \text { Fat }\end{array}$ & $\begin{array}{l}\text { Oral administration } \\
\text { immediate or } 3 \mathrm{~h} \text { post- } \\
\text { ex. }\end{array}$ & $\begin{array}{l}60 \text { min cycling } \\
@ 60 \% \max \\
\mathrm{VO}_{2}\end{array}$ & $\begin{array}{l}\text { - Blood every } 15 \\
\text { min. before ex. } \\
\text { - Arterial and venous } \\
\text { blood every } 30 \\
\text { min. post-ex. For } \\
180 \text { min. }\end{array}$ & $\begin{array}{l}\text { - Early intake of a nutrient supplement enhances } \\
\text { greater accretion of whole body and leg protein } \\
\text { compared to late ingestion. }\end{array}$ \\
\hline $\begin{array}{l}\text { Tarnopolsky et al. } \\
1997^{66}\end{array}$ & $\begin{array}{l}8 \mathrm{M}, 8 \mathrm{~F} \text { trained } \\
\text { endurance } \\
\text { athletes }\end{array}$ & $\begin{array}{l}\text { groups: } \\
\text { - Placebo (PLA) } \\
\text { - CHO }(1 \mathrm{~g} / \mathrm{kg}) \\
\text { - CHO }(0.75 \mathrm{~g} / \mathrm{kg}) \\
\text { + PRO } \\
(0.1 \mathrm{~g} / \mathrm{kg})+\text { Fat } \\
(0.02 \mathrm{~g} / \mathrm{kg})\end{array}$ & $\begin{array}{l}\text { Two oral doses of each } \\
\text { supplement: } \\
\text { - Immediately post-ex. } \\
\text { - } 1 \text { h post-ex. }\end{array}$ & $\begin{array}{l}-90 \text { min. cycle } \\
\text { ergometer at } \\
65 \% \max \mathrm{VO}_{2}\end{array}$ & $\begin{array}{l}\text { - Blood samples were } \\
\text { given pre-ex., } \\
\text { during ex. And } 3 \mathrm{~h} \\
\text { and } 4 \mathrm{~h} \text { post-ex. } \\
-3 \text { post-ex biopsies } \\
\text { (immediate, } 1 \mathrm{~h} 4 \mathrm{~h} \text { ) }\end{array}$ & $\begin{array}{l}\text { - Glucose and insulin increased in both trials post-ex } \\
\text { w/no gender effect } \\
\text { - Glycogen resynthesis increased in both trials vs. } \\
\text { PLA w/no gender effect }\end{array}$ \\
\hline $\begin{array}{l}\text { Borsheim et al. } \\
2004^{52}\end{array}$ & $\begin{array}{l}16(10 \mathrm{M}, 6 \mathrm{~F}) \\
\text { recreationally } \\
\text { active subjects }\end{array}$ & $\begin{array}{l}\text { Two conditions: } \\
\text { - 100g CHO } \\
\text { - Placebo (PLA) } \\
\text { solution }\end{array}$ & $\begin{array}{l}\text { Oral ingestion at } 1 \mathrm{~h} \\
\text { post-ex. }\end{array}$ & $\begin{array}{l}\text { - Leg press }(10 \mathrm{x} \\
8 \text { reps)@ } 80 \% \\
1 \text { Rmprior to } 4 \mathrm{~h} \\
\text { bed rest } \\
\text { - } 2 \text { min. rest } \\
\text { between sets } \\
\end{array}$ & $\begin{array}{l}\text { - Arteriovenous } \\
\text { blood every } \sim 20 \\
\text { min. for } 4 \text { h post- } \\
\text { ex. } \\
\text { - } 4 \text { biopsies } \\
\text { pre/3 post-ex.) }\end{array}$ & $\begin{array}{l}\text { - CHO ingestion improved PRO balance after RE } \\
\text { - Effect, however, was minor and delayed compared } \\
\text { with ingestion of AA }\end{array}$ \\
\hline Roy et al. $2000^{67}$ & $\begin{array}{l}10 \text { young } \\
(19-21 \mathrm{y}) \text {, healthy } \\
\text { males }\end{array}$ & $\begin{array}{l}\text { - Placebo (PLC) } \\
\text { - } \mathrm{CHO}(1 \mathrm{~g} / \mathrm{kg}) \\
\text { - } \mathrm{CHO} / \mathrm{PRO} / \mathrm{Fat} \\
\quad(1 \mathrm{~g} / \mathrm{kg})\end{array}$ & $\begin{array}{l}\text { Immediately post-ex and } \\
1 \mathrm{~h} \text { post-ex. }\end{array}$ & $\begin{array}{l}-9 \text { resistance } \\
\text { training } \\
\text { exercises } \\
-3 \text { sets@ @ } 80 \% \\
\text { 1RM } \\
\end{array}$ & $\begin{array}{l}\text { - Arterial/venous } \\
\text { blood samples } \\
\text { every } \sim 20 \mathrm{~min} . \\
\text { post-ex. } \\
\text { - } 24 \mathrm{~h} \text { urine } \\
\end{array}$ & $\begin{array}{l}\text { - Nonoxidative leucine disposal (marker of protein } \\
\text { synthesis) was increased } 4 \mathrm{~h} \text { for } \mathrm{CHO} / \mathrm{PRO} / \text { Fat } \\
\text { and CHO immediately and } 1 \mathrm{~h} \text { following resistance } \\
\text { training. }\end{array}$ \\
\hline $\begin{array}{l}\text { Tipton et al. } \\
2001^{3}\end{array}$ & $\begin{array}{l}\text { 3M, 3F completed } \\
\text { one PRE and } \\
\text { POST session }\end{array}$ & $\begin{array}{l}\text { EAC: } 6 \mathrm{~g} \text { EAA }+ \\
\text { 35g CHO } \\
\text { PLA: Sweetened } \\
\text { water }\end{array}$ & $\begin{array}{l}\text { PRE: EAC solution pre- } \\
\quad \text { ex. } \\
\text { POST: EAC solution } \\
\text { post-ex. }\end{array}$ & $\begin{array}{l}\text { - Leg press and } \\
\text { leg ext. 8-10 } \\
\text { sets x } 8 \text { reps @ } \\
80 \% 1 \text { RM } \\
\text { - } 2 \text { min. rest } \\
\text { between sets }\end{array}$ & $\begin{array}{l}\text { - } 16 \text { venous and } \\
\text { arterial blood } \\
\text { samples pre-, } \\
\text { during and post- } \\
\text { ex. Over } 180 \text { min. } \\
\text { - Muscle biopsies @ } \\
\text {-60, } 0,60 \text { and } 120 \\
\text { min. }\end{array}$ & $\begin{array}{l}\text { - AA delivery increased w/ex. And } 2 \mathrm{~h} \text { post-ex. In } \\
\text { both trials } \\
\text { - PRO synthesis increased compared to post } \\
\text { - PRE AA uptake was increased } 160 \% \text { more than in } \\
\text { POST } \\
\text { - EAC promoted positive } \mathrm{N} \text { balance in both trials }\end{array}$ \\
\hline $\begin{array}{l}\text { Borsheim et al. } \\
2004^{57}\end{array}$ & $\begin{array}{l}8 \text { subjects } \\
\text { participated in } \\
\text { both trials }\end{array}$ & $\begin{array}{l}\text { Oral doses of: } \\
-77.4 \mathrm{~g} \mathrm{CHO}+ \\
17.5 \mathrm{~g} \text { Whey }+ \\
\text { 4.9g AA } \\
\text { (PAAC) } \\
\text { - } 100 \mathrm{~g} \mathrm{CHO} \mathrm{(P)}\end{array}$ & $1 \mathrm{~h}$ post-exercise & $\begin{array}{l}\text { - Resistance } \\
\text { exercise }\end{array}$ & $\begin{array}{l}\text { - Femoral artery, vein } \\
\text { and muscle } \\
\text { biopsies were } \\
\text { collected for } 3 \mathrm{~h} \\
\text { post-ex. }\end{array}$ & $\begin{array}{l}\text { - PAAC caused an immediate increase and a delayed } \\
\text { increase in protein balance } \\
\text { - PAAC stimulated a greater increase in PRO } \\
\text { synthesis vs. CHO after resistance training. }\end{array}$ \\
\hline $\begin{array}{l}\text { Tipton et al. } \\
1999^{54}\end{array}$ & $3 \mathrm{M}, 3 \mathrm{~F}$ & $\begin{array}{l}\text { Three solutions: } \\
\text { - 40g CHO (PLA) } \\
\text { - 40g mixed AA } \\
\text { - 40g EAA }\end{array}$ & $\begin{array}{l}\text { - Continual }(100 \mathrm{~mL}) \\
\text { consumption every } \\
15-20 \text { min. from } 1 \mathrm{~h} \\
\text { post-ex. To } 4 \mathrm{~h} \text { post- } \\
\text { ex. }\end{array}$ & $\begin{array}{l}\text { - Leg Press }(5 \mathrm{x} \\
10 \text { reps @ } 75 \% \\
1 \mathrm{RM}) \\
\text { - Squat, leg } \\
\text { curls/ext. (4x } 8 \\
\text { reps @ } 75 \% \\
1 \mathrm{RM} \\
\end{array}$ & $\begin{array}{l}\text { - Arteriovenous } \\
\text { blood at }-120,30, \\
220,260 \text { and } 270 \\
\text { min. } \\
\text { - Muscle biopsy was } \\
\text { taken at } 270 \text { min. }\end{array}$ & $\begin{array}{l}\text { - Both MAA and EAA increased net protein balance } \\
\text { - No difference in protein balance between MAA and } \\
\text { EAA suggests no need for NEAA to cause protein } \\
\text { synthesis }\end{array}$ \\
\hline
\end{tabular}




\begin{tabular}{|c|c|c|c|c|c|c|}
\hline $\begin{array}{l}\text { Tipton et al. } \\
2003^{60}\end{array}$ & $4 \mathrm{~F}, 3 \mathrm{M}$ & $\begin{array}{l}\text { Two conditions: } \\
\text { - REST } \\
\text { - REST + EAA+ } \\
\text { EX }\end{array}$ & $\begin{array}{l}\text { - } 15 \text { g EAA solution } \\
\text { before and after } \\
\text { exercise session }\end{array}$ & $\begin{array}{l}-8 \times 8 \text { reps @ } 80 \% \\
1 \mathrm{RM} \\
-2 \text { min. rest } \\
\text { between sets }\end{array}$ & $\begin{array}{l}\text { - Five biopsies and } \\
\text { A/V blood samples } \\
\text { were taken } \\
\text { throughout entire } \\
24 \text { h protocol. }\end{array}$ & $\begin{array}{l}\text { - AA exchange (ES - REST) @ } 3 \mathrm{~h} \text { and } 24 \mathrm{~h} \text { was not } \\
\text { different } \\
\text { - Acute response of muscle to EAA intake + EX is } \\
\text { additive to rest and thus reflects } 24 \mathrm{~h} \text { response. }\end{array}$ \\
\hline $\begin{array}{l}\text { Tipton et al. } \\
2004^{62}\end{array}$ & $\begin{array}{l}23 \text { healthy } \\
\text { untrained young } \\
\text { males and females }\end{array}$ & $\begin{array}{l}\text { Three conditions: } \\
\text { - Placebo (PLA) } \\
\text { - Casein (CAS) } \\
\text { - Whey protein } \\
\text { (WP) }\end{array}$ & 1h post-ex. & $\begin{array}{l}\text { - Leg ext. } 10 \times 8 \\
\text { reps @ } 80 \% \\
1 \mathrm{RM} \\
-2 \text { min. rest } \\
\text { between sets } \\
\end{array}$ & $\begin{array}{l}\text { - Femoral A/V blood } \\
\text { samples for } 3 \mathrm{~h} \\
\text { post-ex. } \\
\text { - } 4 \text { biopsies (pre-, } 1 \mathrm{~h}, \\
\text { 2h, } 5 \mathrm{~h} \text { post-ex.) } \\
\end{array}$ & $\begin{array}{l}\text { - Both WP and CAS increased PRO balance to } \\
\text { promote PRO synthesis } \\
\text { - AA uptake was increased after exercise in both } \\
\text { groups }\end{array}$ \\
\hline $\begin{array}{l}\text { Ratamess et al. } \\
2003^{37}\end{array}$ & $\begin{array}{l}17 \text { resistance- } \\
\text { trained men }\end{array}$ & $\begin{array}{l}\text { Two conditions: } \\
\text { - Placebo (PLA) } \\
\text { - AA } \\
\text { supplementation }\end{array}$ & $\begin{array}{l}\text { - Immediately post- } \\
\text { workout when } \\
\text { training } \\
\text { - Mornings of no } \\
\text { training }\end{array}$ & $\begin{array}{l}-4 \mathrm{~d} / \text { wk RE } \\
\text { program for } 4 \\
\text { wks } \\
\text { - } 2 \text { wk high- } \\
\text { intensity phases }\end{array}$ & $\begin{array}{l}\text { - Strength, power and } \\
\text { endurance were } \\
\text { determined at end } \\
\text { of week }\end{array}$ & $\begin{array}{l}\text { - Reduction in strength and power was attenuated by } \\
\text { AA supplementation } \\
\text { - High intensity, moderate volume RE is effective to } \\
\text { increase strength and power. }\end{array}$ \\
\hline $\begin{array}{l}\text { Rasmussen et al. } \\
2000^{51}\end{array}$ & $\begin{array}{l}3 \mathrm{M}, 3 \mathrm{~F} \text { in } \\
\text { postabsorptive } \\
\text { state and } \\
\text { recreationally } \\
\text { active }\end{array}$ & $\begin{array}{l}\text { - Placebo drink } \\
\text { (PLA) } \\
\text { - EAA+CHO drink } \\
(35 \mathrm{~g} \mathrm{CHO}+6 \mathrm{~g} \\
\text { EAA) }\end{array}$ & $\begin{array}{l}\text { Two conditions: } \\
\text { - PLA 1h post-ex + } \\
\text { EAA+CHO } 3 \mathrm{~h} \text { post- } \\
\text { ex } \\
\text { - EAA+CHO } 1 \mathrm{~h} \text { post- } \\
\text { ex. + PLA 3h post- } \\
\text { ex. }\end{array}$ & $\begin{array}{l}-8-10 \text { sets } \times 8 \text { reps } \\
\text { @ } 80 \% 1 \mathrm{RM} \\
-2 \text { min. rest } \\
\text { between sets }\end{array}$ & $\begin{array}{l}\text { - } 11 \text { arteriovenous } \\
\text { blood over } 7 \mathrm{~h} \\
\text { time span. } \\
\text { - Muscle biopsies at } \\
45 \text { min, } 2 \text { h and } 4 \\
\text { h post-ex. }\end{array}$ & $\begin{array}{l}\text { - No change in PLA } \\
\text { - EAA+CHO increased PRO balance and PRO SYN } \\
1 \mathrm{~h} \text { and } 3 \mathrm{~h} \text { post-ex. } \\
\text { - No increase in PS and PRO balance at } 3 \mathrm{~h} \text { vs. } 1 \mathrm{~h} \\
\text { with both }>\text { than pre-ex. }\end{array}$ \\
\hline Miller et al. $2003^{53}$ & $6 \mathrm{M}, 4 \mathrm{~F}$ & $\begin{array}{l}\text { - CHO alone } \\
\text { - AA alone } \\
\text { - CHO + mixed } \\
\text { AAs (MIX)* } \\
\text { *50\% EAA } \\
\text { according to wt. }\end{array}$ & $\begin{array}{l}\text { - Two drinks at } 1 \mathrm{~h} \text { and } \\
2 \mathrm{~h} \text { post-ex. } \\
\text { - Infusion was started } \\
1 \mathrm{~h} \text { prior to exercise } \\
\text { and continue } 4 \mathrm{~h} \\
\text { post-ex. }\end{array}$ & $\begin{array}{l}-8-10 \text { sets } x 10 \\
\text { reps of leg press } \\
\text { and leg ext. @ } \\
75 \% 1 \text { RM } \\
-2 \text { min. rest } \\
\text { between sets }\end{array}$ & $\begin{array}{l}\text { - Biopsies at } 30,90, \\
150 \text { and } 210 \text { min. } \\
\text { post-ex. } \\
\text { - Arteriovenous } \\
\text { blood for } 4 \mathrm{~h} \text { post- } \\
\text { ex. }\end{array}$ & $\begin{array}{l}\text { - Combined effects of CHO \& AA after resistance } \\
\text { exercise is equivalent to their independent effects. } \\
\text { - Prior intake of AA+CHO does not diminish } \\
\text { metabolic response to a second comparable dose } \\
\text { 1h later. }\end{array}$ \\
\hline $\begin{array}{l}\text { Borsheim et al. } \\
2002^{1}\end{array}$ & $\begin{array}{l}3 \mathrm{M}, 3 \mathrm{~F} \\
\text { recreationally } \\
\text { active }\end{array}$ & $\begin{array}{l}\text { - 6g Essential } \\
\text { amino acids } \\
\text { (EAA) }\end{array}$ & $\begin{array}{l}\text { - Two oral doses of } 6 \mathrm{~g} \\
\text { EAA at } 1 \mathrm{~h} \text { and } 2 \mathrm{~h} \\
\text { post-ex }\end{array}$ & $\begin{array}{l}\text { - } 8 \text { - } 10 \text { sets } \mathrm{x} 10 \\
\text { reps of leg press } \\
\text { and leg ext. @ } \\
80 \% 1 \mathrm{RM} \\
\text { - } 2 \text { min. rest } \\
\text { between sets }\end{array}$ & $\begin{array}{l}\text { - } 4 \text { muscle biopsies } \\
\text { were provided } \\
\text { post-ex } \\
\text { - Femoral artery and } \\
\text { venous blood } \\
\text { samples } \sim \text { every } 20 \\
\text { min. for } 4 \text { h postex } \\
\end{array}$ & $\begin{array}{l}\text { - PRO balance increased in response to both drinks } \\
\text { and decreased when [AA] returned to basal levels } \\
\text { - Non-essential AA are not necessary for increasing } \\
\text { PRO balance } \\
\text { - PRO synthesis is dose-dependent of [EAA] }\end{array}$ \\
\hline Boirie et al. $1997^{68}$ & $\begin{array}{l}16 \text { young }(24 \pm 4 \\
\text { yrs) healthy } \\
\text { subjects }\end{array}$ & $\begin{array}{l}\text { - 30g whey } \\
-43 \mathrm{~g} \text { casein (equal } \\
\text { [Leu]) } \\
-30 \mathrm{~g} \text { unlabeled } \\
\text { whey } \\
-43 \mathrm{~g} \text { unlabeled } \\
\text { casein } \\
-30 \mathrm{~g} \text { unlabeled } \\
\text { casein }\end{array}$ & $\begin{array}{l}\text { - Feeding Trial } \\
\text { - No exercise } \\
\text { - All conditions were } \\
\quad \text { ingested at same time }\end{array}$ & NONE & $\begin{array}{l}\text { - A/V blood samples } \\
\text { for entire } 7 \mathrm{~h} \text { time } \\
\text { period }\end{array}$ & $\begin{array}{l}\text { - CAS had prolonged plateau of high [AA] inhibiting } \\
\text { PRO breakdown by } 34 \% \\
\text { - WP caused dramatic increase in [AA] causing } 68 \% \\
\text { increase in PRO synthesis } \\
\text { - Speed of PRO digestion and AA absorption have } \\
\text { major effect on protein synthesis. }\end{array}$ \\
\hline
\end{tabular}




\begin{tabular}{|c|c|c|c|c|c|c|}
\hline $\begin{array}{l}\text { Dangin et al. } \\
2003^{69}\end{array}$ & $\begin{array}{l}-9 \text { elderly } \\
\text { ( } 72 \pm 1 \text { yrs }) \\
-6 \text { young } \\
(24 \pm 1 \text { yrs })\end{array}$ & $\begin{array}{l}\text { - Casein protein } \\
\text { (CAS) } \\
\text { - Isonitrogenous whey } \\
\text { w/CAS (WPiC) } \\
\text { - Isonitrogenous whey } \\
\text { w/leucine (WPiL) }\end{array}$ & $\begin{array}{l}\text { - Feeding Trial } \\
\text { - No exercise }\end{array}$ & NONE & $\begin{array}{l}\text { - A/V blood samples } \\
\text { - Muscle biopsies }\end{array}$ & $\begin{array}{l}\text { - Whey digested faster than CAS } \\
\text { - PRO breakdown was not different } \\
\text { - PRO synthesis was highest with WP vs. CAS } \\
\text { irrespective of age }\end{array}$ \\
\hline $\begin{array}{l}\text { Dangin et al. } \\
2001^{70}\end{array}$ & $\begin{array}{l}22 \text { healthy young } \\
\text { males }(25 \pm 1 \text { yrs })\end{array}$ & $\begin{array}{l}\text { - 30g casein } \\
-30 \mathrm{~g} \text { free AA mimic } \\
\text { casein } \\
\text { - 30g whey } \\
\text { - Repeated small } \\
\text { doses of whey }\end{array}$ & $\begin{array}{l}\text { - Feeding Trial } \\
\text { - No exercise }\end{array}$ & NONE & $\begin{array}{l}\text { - A/V blood samples } \\
\text { for entire } 7 \mathrm{~h} \text { time } \\
\text { period }\end{array}$ & $\begin{array}{l}\text { - "Fast" meals (whey and free AA) caused strong, } \\
\text { rapid increase of [AA] } \\
\text { - Moderate increase in [AA] with "slow" meals and } \\
\text { stayed elevated longer } \\
\text { - } 7 \text { h Leu balance was higher after slow vs. fast meals }\end{array}$ \\
\hline Volpi et al. $1998^{71}$ & $(71 \pm 2$ yrs $)$ & $\begin{array}{l}\text { - Infusion of an AA } \\
\text { mixture }\end{array}$ & $\begin{array}{l}\text { - Postabsorptive vs. } \\
\text { Infusion state }\end{array}$ & NONE & $\begin{array}{l}\text { - Muscle PRO } \\
\text { synthesis and } \\
\text { breakdown } \\
\text { - A/V blood } \\
\text { - Muscle biopsies }\end{array}$ & $\begin{array}{l}\text { - Muscle PRO synthesis increased in response to AA } \\
\text { infusion } \\
\text { - Muscle PRO breakdown did not change thus } \\
\text { increasing PRO balance. }\end{array}$ \\
\hline $\begin{array}{l}\text { Paddon-Jones et al. } \\
2004^{72}\end{array}$ & $\begin{array}{l}-6 \text { Young } \\
(34 \pm 4 \text { yrs }) \\
-7 \text { Older } \\
(67 \pm 2 \text { yrs })\end{array}$ & $\begin{array}{l}\text { - One single oral dose } \\
\text { of } 15 \mathrm{~g} \text { EAA } \\
\text { solution }\end{array}$ & $\begin{array}{l}\text { - Pre-/post- } \\
\text { supplementation } \\
\text { measures were taken. }\end{array}$ & NONE & $\begin{array}{l}\text { - A/V blood samples } \\
\text { and muscle biopsies } \\
\text { were taken for } 3 \mathrm{~h} \\
\text { pre- and } 4 \mathrm{~h} \text { post- } \\
\text { supplementation } \\
\end{array}$ & $\begin{array}{l}\text { - EAA increased PRO synthesis in both young and old } \\
\text { - Increase in [AA] was slower in elderly subjects but } \\
\text { remained elevated for a longer period. } \\
\text { - No overall diff. in PRO synthesis between young } \\
\text { and old. }\end{array}$ \\
\hline $\begin{array}{l}\text { Esmarck et al. } \\
2001^{55}\end{array}$ & $\begin{array}{l}\text { 13M older } \\
\text { individuals } \\
(74.1 \pm 1 \mathrm{yr})\end{array}$ & $\begin{array}{l}\text { - Liquid supplement } \\
\text { (10g PRO }+7 \mathrm{~g} \\
\text { CHO }+3 \mathrm{~g} \text { fat })\end{array}$ & $\begin{array}{l}\text { - Immediately post } \\
\text { training session }(\mathrm{P} 0) \\
-2 \mathrm{~h} \text { post training } \\
\text { session }(\mathrm{P} 2)\end{array}$ & $\begin{array}{l}-12 \text { week RE } \\
\text { program } \\
\text { (3x/week) }\end{array}$ & $\begin{array}{l}\text { - Body comp. } \\
\text { (DEXA) } \\
\text { - Hypertrophy via } \\
\text { MRI, and muscle } \\
\text { biopsies } \\
\text { - Isokinetic strength } \\
\end{array}$ & $\begin{array}{l}\text { - P0 > P2 for cross-sect. area and mean fiber area } \\
\text { - Similar change in strength } \\
\text { - Immediate protein supplementation post-ex. } \\
\text { promotes more growth in elderly males }\end{array}$ \\
\hline Volpi et al. $2000^{73}$ & $\begin{array}{l}4 \mathrm{M}, 1 \mathrm{~F} \text { young } \\
(30 \pm 3 \text { yrs }) \\
4 \mathrm{M}, 1 \mathrm{~F} \text { elderly } \\
(72 \pm 1 \text { yrs })\end{array}$ & $\begin{array}{l}\text { - Resting or basal } \\
\text { phase } \\
\text { - } 40 \mathrm{~g} \text { glucose }+40 \mathrm{~g} \\
\text { mixed AA }\end{array}$ & $\begin{array}{l}\text { Subjects completed a: } \\
-300 \text { min. resting } \\
\text { period } \\
-180 \mathrm{~min} . \text { supplement } \\
\text { period }\end{array}$ & NONE & $\begin{array}{l}\text { - AV samples every } \\
10 \text { min. last } 60 \\
\text { min. } \\
\text { - } 4 \text { biopsies in } 480 \\
\text { min. }\end{array}$ & $\begin{array}{l}\text { - AA turnover was similar in young and old. } \\
\text { - PRO synthesis with high [AA] and [insulin] was } \\
\text { blunted in elderly compared to young. }\end{array}$ \\
\hline Volpi et al. $2003^{74}$ & $\begin{array}{l}14 \text { elderly adults } \\
\text { ( } 70 \pm 2 \text { yrs) }\end{array}$ & $\begin{array}{l}\text { - } 18 \mathrm{~g} \text { EAA } \\
-40 \mathrm{~g} \text { Mixed AA } \\
(18 \mathrm{~g} \text { EAA+22g } \\
\text { NEAA })\end{array}$ & $\begin{array}{l}\text { Small oral boluses } \\
\quad \text { every } 10 \mathrm{~min} \text {. for } 3 \mathrm{~h}\end{array}$ & NONE & $\begin{array}{l}\text { Protein metabolism } \\
\text { was measured via: } \\
\text { - A/V blood } \\
\text { - Muscle biopsies }\end{array}$ & $\begin{array}{l}\text { - AA balance increased in similar amounts from } \\
\text { resting in both conditions } \\
\text { - EAA are responsible for PRO synthesis in elderly. }\end{array}$ \\
\hline $\begin{array}{l}\text { Andersen et al. } \\
2005^{63}\end{array}$ & & $\begin{array}{l}\text { - Isoenergetic CHO } \\
\text { vs. PRO }\end{array}$ & $\begin{array}{l}\text { - Before and after RE } \\
\text { - Morning on non- } \\
\text { training days }\end{array}$ & $\begin{array}{l}\text { 14-week RE } \\
\text { program }\end{array}$ & $\begin{array}{l}\text { - Muscle cross- } \\
\text { sectional area } \\
\text { - Strength }\end{array}$ & $\begin{array}{l}\text { - PRO increased Type I/II fibers more than CHO } \\
\text { - Squat jump height increased in PRO vs. CHO }\end{array}$ \\
\hline
\end{tabular}




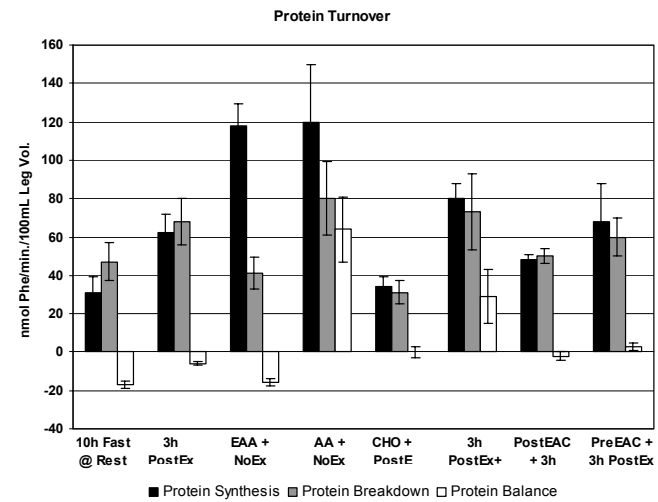

Tipton et al. sought to provide some answers to this question by having six subjects either ingest a solution containing $6 \mathrm{~g}$ EAA $+35 \mathrm{~g}$ $\mathrm{CHO}$, immediately before or immediately after they completed an acute bout of resistance training. ${ }^{3}$ Findings from this study revealed that consuming a small dose of EAA with some carbohydrate immediately before an acute resistance exercise bout was more effective at stimulating protein synthesis and improving protein balance when compared to ingesting the nutrients immediately after the workout. This study is the only study to date to quantitatively determine any changes in protein synthesis when considering the timing of ingestion before or after the exercise bout. In summary, many studies have provided support for ingesting different nutrients anywhere from immediately after to $3 \mathrm{~h}$ after exercise for promoting increases in protein synthesis, however, ingesting a combination of EAA + CHO immediately prior to the workout may stimulate the most profound changes.

\section{SATURATION OF MUSCLE PROTEIN SYNTHESIS}

One thing that should be apparent from these findings is that a high concentration of amino acids causes a pronounced increase in protein synthesis. While many studies have illustrated responses that support this statement, $1,2,47,51,57$ recent findings have suggested the body may not always respond accordingly. While these findings are less conclusive, an infusion study by Bohe et al. over a $6 \mathrm{~h}$ time period was found to largely increase protein synthesis ( 2.8-fold) for around $2 \mathrm{~h}$ but then returned to basal levels for the remaining $4 \mathrm{~h}$ of the infusion even though supra-physiological concentrations of amino acids were present. ${ }^{58}$ The authors concluded that muscle protein synthesis responds rapidly to an increase in amino acid availability but that the mechanistic machinery may no longer operate at elevated levels once its substrate requirements are met, which would also explain the concomitant increase in ureagenesis seen with this study. The results of this study conflict, however, with the recent reports by Kobayashi and a follow-up study by Bohe, which concluded that extracellular amino acid concentration was the primary response element to stimulate protein synthesis. ${ }^{30,59}$ Additionally, a previous study by Borsheim demonstrated that an almost equal response in protein synthesis can be seen after consumption of a second equal $6 \mathrm{~g}$ dose of EAA $1 \mathrm{~h}$ after an initial $6 \mathrm{~g}$ dose. . In all of these studies, $^{1,30,59}$ no conclusive determination can be made to support the theory that an environment was created by their experiment that resulted in a prolonged elevation of amino acids which caused the mechanistic machinery responsible for causing protein synthesis to be overwhelmed. Kobayashi et al. used a dialysis model in laboratory swine to decrease extracellular amino acid concentrations and then infused amino acids to subsequently increase the amino acid concentrations to make their conclusions. While their findings support the role of extracellular amino acids in stimulating protein synthesis, it cannot be concluded that the mechanistic machinery was "flooded" or overwhelmed as previously stated. ${ }^{30}$ The importance of these findings relate to the amount of protein or amino acid that should be ingested in order to derive the greatest increase in protein synthesis. While an apparent flooding or overwhelming of the mechanism(s) associated with amino acid transport and subsequent protein synthesis is possible, ${ }^{58}$ other studies have illustrated that practical patterns of ingesting small doses of amino acids after resistance exercise can be an effective way to stimulate protein 
synthesis. ${ }^{1,57,60}$ In this regard, what the future holds for the optimal dosage of amino acids through ingestion remains to be determined. While the current research has provided some evidence of a dose-response relationship, ${ }^{58,59}$ no studies to date have been completed that have comparatively tested the optimal amount of amino acid delivery when ingested.

\section{INTACT PROTEIN SUPPLEMENTS}

The time course and impact on ingesting relatively intact forms of protein (e.g. soy, casein, whey, colostrum) will be discussed next. These types of supplements are some of the most popular in the nutritional supplement industry with literally hundreds of different possibilities. ${ }^{61}$ The information provided within this review is intended to help the reader to better understand optimal delivery, timing and composition of nutrients in regards to optimizing net muscle protein balance. However, almost all of the studies discussed so far have employed infusion of free amino acids or ingestion of free amino acid solutions as opposed to the intact proteins that are commonly ingested. While the constituents of both forms may be similar it is possible that the intact proteins may not respond in the same manner. Fortunately, many studies have been conducted to determine overall training adaptations while ingesting some common forms of these supplements which have demonstrated some positive results. ${ }^{33-36,62,63}$ Few studies, however, have been conducted on intact proteins to determine their impact on whole-body and leg fractional protein synthesis, protein breakdown and protein balance. Recent studies have helped to provide some preliminary answers in this regard. ${ }^{57,62}$ A 2005 study by Andersen and colleagues resistance trained participants for 14 weeks while they consumed either a protein or carbohydrate supplement before and after theirs workouts in addition to the mornings of non-training days. Their findings indicated that administration of the protein supplement resulted in greater increases in cross-sectional muscle size of
Type I and II fibers as well as a greater increase in squat jump height. ${ }^{63}$ In another investigation, eight subjects participated in both trials and ingested either $100 \mathrm{~g} \mathrm{CHO}$ or a mixture of whey protein (17.5 g), CHO (77.4 g) and amino acids ( $4.9 \mathrm{~g}), 1 \mathrm{~h}$ after completing an acute bout of resistance training. The authors concluded that the mixture of nutrients provided two responses, an immediate response and a smaller delayed response, which resulted in a greater overall stimulation of muscle protein synthesis when compared to $100 \mathrm{~g} \mathrm{CHO}^{57}$ The next study utilizing intact forms of protein supplements was the first and currently the only study to compare different forms of intact protein for changes in amino acid kinetics and resulting protein balance. Tipton and investigators compared a $20 \mathrm{~g}$ dose of whey protein, placebo, or a $20 \mathrm{~g}$ dose of casein protein that was ingested $1 \mathrm{~h}$ after completing a standard resistance training bout. While the pattern of amino acids release and uptake by skeletal muscle was different, the overall amino acid uptake was similar between the two types of protein resulting in similar changes in protein balance when compared to placebo. ${ }^{62}$

Furthermore, the authors stated that the increases seen in this study were comparable to those studies that have been previously discussed that used free amino acids. Until recently, research has been scarce highlighting the actual response of skeletal muscle to intact protein sources that are so commonly ingested by resistance training athletes. These two studies help to illustrate that these forms of protein are effective at stimulating or sustaining the overall balance of muscle protein while resistance training.

\section{SUMMARY}

The impact of resistance training on muscle hypertrophy is well known. For years, resistance training athletes have been interested in identifying which forms of nutritional supplementation will provide the greatest support in an effort to maximize the training adaptations from resistance training. Many findings and suggestions have been 
reported in this regard and are outlined below:

- Resistance training modestly stimulates protein synthesis and further stimulates protein breakdown resulting an overall negative protein balance after exercise.

- As the training status of an individual progresses, the magnitude of changes seen in protein synthesis and breakdown diminishes after each exercise bout as well as a diminished increase of protein synthesis after each subsequent exercise bout.

- Infusion or ingestion of amino acids is an effective way to increase amino acid concentrations at rest or after resistance exercise.

- Availability of amino acids after resistance exercise increases protein synthesis.

- Essential amino acids do appear to play a primary role in protein synthesis and adding carbohydrate to them may enhance this effect.

- Ingestion of carbohydrate alone after resistance exercise causes marginal improvements in overall protein synthesis while maintaining a negative net protein balance. No studies have found carbohydrate to be detrimental and it may be useful to enhance palatability; however the additional caloric burden may not be desired.

- A small dose of essential amino acids after resistance exercise has been found to stimulate protein synthesis to a similar degree when compared to studies that used much larger doses of both amino acids (EAA, NEAA, or both) or that were combined with carbohydrate.

- Ingestion of amino acids after resistance exercise has been shown at many different time points in several studies to stimulate increases in muscle protein synthesis, cause minimal changes in protein breakdown and increase overall protein balance. It has not been conclusively determined what time point is optimal. Similar changes have been found for studies that have administered amino acids alone or with carbohydrate immediately upon completion of an acute exercise bout, $1 \mathrm{~h}$ after completion, $2 \mathrm{~h}$ after completion and $3 \mathrm{~h}$ after completion. Interestingly, ingesting nutrients before the exercise bout may have the most benefit of all the time points.

- It is possible for the mechanisms involving amino acid transport and protein synthesis to be overwhelmed with extremely high, continuous levels of amino acids. The likelihood of this occurring is rare even upon considering the highest of protein intakes among individuals.

- An optimal dosage in which to ingest amino acids at this time does not exist. Studies using similar techniques while resistance training have used $6 \mathrm{~g}$ EAA only, $6 \mathrm{~g}$ EAA +6 g NEAA, 12 g EAA only, $17.5 \mathrm{~g}$ whey protein, $20 \mathrm{~g}$ casein protein, $20 \mathrm{~g}$ whey protein, $40 \mathrm{~g}$ mixed amino acid, $40 \mathrm{~g}$ EAA only all with similar increases in protein synthesis and protein balance. Athletes who desire to increase muscle mass or are involved in power sports should consider consuming protein supplements that will provide amino acids in similar amounts used in these studies.

- Intact proteins or combinations of them that are commonly used in popular protein supplements appear to elicit similar increases in protein balance after resistance training as compared to other studies using free amino acids.

From these primary findings, it is our hope that athletes, coaches, nutritionists and researchers will be able to provide clearer advice and recommendations when consulting themselves, their players, clients, or research participants in regards to optimal administration of nutrients while participating in a resistance training program. 


\section{REFERENCES}

1 Borsheim E, Tipton KD, Wolf SE, et al.: Essential amino acids and muscle protein recovery from resistance exercise. American Journal of Physiology, Endocrinology and Metabolism 2002, 283:E648-657.

2 Tipton KD, Ferrando AA, Phillips SM, et al.: Postexercise net protein synthesis in human muscle from orally administered amino acids. Am J Physiol Endocrinol Metab 1999, 276:E628-E634.

3 Tipton KD, Rasmussen BB, Miller SL, et al.: Timing of amino acid-carbohydrate ingestion alters anabolic response of muscle to resistance exercise. Am J Physiol Endocrinol Metab 2001, 281:E197-E206.

4 Liu Z, Barrett EJ: Human protein metabolism: its measurement and regulation. Am J Physiol Endocrinol Metab 2002, 283:E1105-E1112.

5 Wagenmakers A: Skeletal muscle amino acid transport and metabolism. In: Biochemistry of Exercise X. Edited by: Hargreaves M, Thompson M. Champaign, IL:Human Kinetics; 1999:217-231.

6 Rennie MJ, Tipton KD: Protein and amino acid metabolism during and after exercise and the effects of nutrition. Annu Rev Nutr 2000, 20:457-483.

7 Wolfe RR: Effects of amino acid intake on anabolic processes. Can J Appl Physiol 2001, 26:S220-227.

8 Wolfe RR: Regulation of muscle protein by amino acids. J Nutr 2002, 132:3219S-3224.

9 Pitkanen HT, Nykanen T, Knuutinen J, et al.: Free amino acid pool and muscle protein balance after resistance exercise. Med Sci Sports Exerc 2003, 35(5):784-792.

10 Biolo G, Fleming RYD, Maggi SP, et al.: Inverse regulation of protein turnover and amino acid transport in skeletal muscle of hypercatabolic patients. J Clin Endocrinol Metab 2002, 87:3378-3384.

11 Biolo G, Maggi SP, Williams BD, et al.: Increased rates of muscle protein turnover and amino acid transport after resistance exercise in humans. Am J Physiol Endocrinol Metab 1995, 268:E514-E520.

12 Phillips SM, Tipton KD, Aarsland A, et al.: Mixed muscle protein synthesis and breakdown after resistance exercise in humans. American Journal of Physiology, Endocrinology and Metabolism 1997, 273:E99-E107.

13 Blomstrand E, Ek S, Newsholme EA: Influence of ingesting a solution of branched chain amino acids on plasma and muscle concentration of amino acids during prolonged submaximal exercise. Nutrition 1996, 12:485-490.

14 Sheffield-Moore M, Yeckel CW, Volpi SE, et al.: Postexercise protein metabolism in older and younger men following moderate-intensity aerobic exercise. American Journal of Physiology, Endocrinology and Metabolism 2004, 287:E513-E522.

15 Phillips SM, Tipton KD, Ferrando AA, et al.: Resistance training reduces the acute exercise-induced increase in muscle protein turnover. Am J Physiol 1999, 276:E118-E124.

16 Rasmussen BB, Phillips SM: Contractile and nutritional regulation of human muscle growth. Exerc Sport Sci Rev 2003, 31(3):127-131.

17 Tipton KD, Ferrando AA, Williams BD, et al.: Muscle protein metabolism in female swimmers after a combination of resistance and endurance exercise. J Appl Physiol 1996, 81(5):2034-2038.

18 MacDougal JD, Gibala MJ, Tarnopolsky MA, et al.: The time course for elevated muscle protein synthesis following heavy resistance exercise. Can J Appl Physiol 1995, 20:480-486.

19 Phillips SM, Parise G, Roy BD, et al.: Resistance-training-induced adaptations in skeletal muscle protein turnover in the fed state. Can J Physiol Pharmacol 2002, 80(11):1045-1053.

20 Roth SM, Martel GF, Frederick MI, et al.: Ultrastructural muscle damage in young vs. old men after high-volume, heavyresistance strength training. J Appl Physiol 1999, 86(6):1833-1840.

21 Gibala MJ, Interisano SA, Tarnopolsky MA, et al.: Myofibrillar disruption following acute concentric and eccentric resistance exercise in strength-trained men. Can J Physiol Pharmacol 2000, 78(8):656-661.

22 Willoughby DS, Taylor L, Taylor M: Glucocorticoid receptor and ubiquitin expression after repeated eccentric exercise. Med Sci Sports Exerc 2003, 35(12):2023-2031.

23 Willoughby DS, McFarlin B, Bois C: Interleukin-6 expression after repeated bouts of eccentric exercise. Int J Sports Med 2003, 24:15-21.

24 Hasten DL, Pak-Loduca J, Obert KA, et al.: Resistance exercise acutely increases MHC and mixed muscle protein synthesis rates in 78-84 and 23-32 yr olds. Am J Physiol Endocrinol Metab 2000, 278:E620-E626.

25 Willoughby DS, Rosene J: Effects of oral creatine and resistance training on myosin heavy chain expression. Med Sci Sports Exerc 2001, 33(10):1674-1681.

26 Rennie MJ: Control of muscle protein synthesis as a result of contractile activity and amino acid availability: Implications for protein requirements. International Journal of Sport Nutrition and Exercise Metabolism 2001, 11:S170-S176.

27 Gautsch TA, Anthony JC, Kimball SR, et al.: Availability of eIF4E regulates skeletal muscle protein synthesis during recovery from exercise. Am J Physiol 1998, 274(2 Pt 1):C406-414.

28 Kimball SR, Farrell PA, Jefferson LS: Invited Review: Role of insulin in translational control of protein synthesis in skeletal muscle by amino acids or exercise. J Appl Physiol 2002, 93(3):1168-1180.

29 Kimball SR, Jefferson LS: Amino acids as regulators of gene expression. Nutr Metab (Lond) 2004, 17(1):3.

30 Kobayashi H, Borsheim E, Anthony TG, et al.: Reduced amino acid availability inhibits muscle protein synthesis and decreases activity of initiation factor eIF2B. American Journal of Physiology, Endocrinology and Metabolism 2003, 284:E488E498.

31 Anthony JC, Anthony TG, Kimball SR, et al.: Signaling pathways involved in translational control of protein synthesis in skeletal muscle by leucine. J Nutr 2001, 131(3):856S-860S.

32 Bolster DR, Jefferson LS, Kimball SR: Regulation of protein synthesis associated with skeletal muscle hypertrophy by insulin, amino acid- and exercise-induced signalling. Proc Nutr Soc 2004, 63(2):351-356.

33 Kerksick C, Kreider R, Rasmussen C, et al.: Effects of bovine colostrum supplementation on training adaptations II: Performance. FASEB J 2001, 15:LB316. 
34 Kreider RB, Klesges R, Harmon K, et al.: Effects of ingesting supplements designed to promote lean tissue accretion on body composition during resistance training. Int J Sport Nutr 1996, 6:234-246.

35 Kreider R, Rasmussen C, Kerksick C, et al.: Effects of bovine colostrum supplementation on training adaptations I: Body composition. FASEB J 2001, 15:LB 316.

36 Kreider R, Kerksick C, Rasmussen C, et al.: Effects of whey protein supplementation with casein or BCAA \& glutamine on training adaptations I: Body composition. [abstract]. Med Sci Sports Exerc 2003, 35(5):S395.

37 Ratamess NA, Kraemer WJ, Volek JS, et al.: The effects of amino acid supplementation on muscular performance during resistance training overreaching. J Strength Cond Res 2003, 17(2):250-258.

38 Rennie MJ, Bohe J, Wolfe RR: Latency, duration and dose response relationships of amino acid effects on human muscle protein synthesis. Journal of Nutrition 2002, 132(3225S-3227S)

39 Gibala MJ: Nutrtional supplementation and resistance exercise: what is the evidence for enhanced skeletal muscle hypertrophy? Can J Appl Physiol 2000, 25(6):524-535.

40 Lemon PW, Berardi JM, Noreen EE: The role of protein and amino acid supplements in the athlete's diet: does type or timing of ingestion matter? Curr Sports Med Rep 2002, 1(4):214-221.

41 Tipton KD, Wolfe RR: Protein and amino acids for athletes. J Sports Sci 2004, 22(1):65-79.

42 Mosoni L, Mirand PP: Type and timing of protein feeding to optimize metabolism. Curr Opin Clin Nutr Metab Care 2003, 6(3):301-306.

43 Tipton KD, Wolfe RR: Exercise, protein metabolism, and muscle growth. Int J Sport Nutr Exerc Metab 2001, 11(1):109-132.

44 Biolo G, Williams BD, Fleming RYD, et al.: Insulin action on muscle protein kinetics and amino acid transport during recovery after resistance exercise. Diabetes 1999, 48:949-957.

45 Paddon-Jones D, Sheffield-Moore M, Creson DL, et al.: Hypercortisolemia alters muscle protein anabolism following ingestion of essential amino acids. American Journal of Physiology, Endocrinology and Metabolism 2003, 284:E946-E953.

46 Wolfe RR: Control of muscle protein breakdown: Effects of activity and nutritional states. Int J Sport Nutr Exerc Metab 2001, 11:S164-S169.

47 Biolo G, Tipton KD, Klein S, et al.: An abundant supply of amino acids enhances the metabolic effect of exercise on muscle protein. Am J Physiol 1997, 273(1 Pt 1):E122-129.

48 Biolo G, Fleming RYD, Wolfe RR: Physiologic hyperinsulinemia stimulates protein synthesis and enhances transport of selected amino acids in human skeletal muscle. J Clin Invest 1995, 95:811-819.

49 Biolo G, Fleming RYD, Maggi SP, et al.: Transmembrane transport and intracellular kinetics of amino acids in human skeletal muscle. Am J Physiol Endocrinol Metab 1995, 268:E75-E84.

50 Biolo G, Chinkes DL, Zhang X-J, et al.: A new model to determine in vivo the relationship between amino acid transmembrance transport and protein kinetics in muscle. J Parent Enter Nutr 1992, 16:305-315.

51 Rasmussen BB, Tipton KD, Miller SL, et al.: An oral essential amino acid-carbohydrate supplement enhances muscle protein anabolism after resistance exercise. J Appl Physiol 2000, 88:386-392.

52 Borsheim E, Cree MG, Tipton KD, et al.: Effect of carbohydrate intake on net muscle protein synthesis during recovery from resistance exercise. Journal of Applied Physiology 2004, 96:674-678.

53 Miller SL, Tipton KD, Chinkes DL, et al.: Independent and combined effects of amino acids and glucose after resistance exercise. Medicine and Science in Sports and Exercise 2003, 35(3):449-455.

54 Tipton KD, Gurkin BE, Matin S, et al.: Nonessential amino acids are not necessary to stimulate net muscle protein synthesis in healthy volunteers. J Nutr Biochem 1999, 10:89-95.

55 Esmarck B, Andersen JL, Olsen S, et al.: Timing of postexercise protein intake is important for muscle hypertrophy with resistance training in elderly humans. J Physiol 2001, 535(1):301-311.

56 Levenhagen DK, Gresham JD, Carlson MG, et al.: Postexercise nutrient intake timing in humans is critical to recovery of leg glucose and protein homeostasis. American Journal of Physiology, Endocrinology and Metabolism 2001, 280:E982-E993.

57 Borsheim E, Aarsland A, Wolfe RR: Effect of an amino acid, protein, and carbohydrate mixture on net muscle protein balance after resistance exercise. International Journal of Sport Nutrition and Exercise Metabolism 2004, 14(3):255-271.

58 Bohe J, Low A, Wolfe RR, et al.: Latency and duration of stimulation of human muscle protein synthesis during continuous infusion of amino acids at rest. J Physiol 2001, 532:575-579.

59 Bohe J, Low A, Wolfe RR, et al.: Human muscle protein synthesis is modulated by extracellular, not intramuscular amino acid availability: A dose-response study. Journal of Physiology 2003, 552(1):315-324.

60 Tipton KD, Borsheim E, Wolf SE, et al.: Acute response of net muscle protein balance reflects 24-h balance after exercise and amino acid ingestion. Am J Physiol Endocrinol Metab 2003, 284:E76-E89.

61 Di Pasquale M: Proteins and amino acids in exercise and sport. In: Energy-Yielding Macronutrients and Energy Metabolism in Sports Nutrition. Edited by: Driskell J, Wolinsky I. Boca Raton:CRC Press; 1999:119-162.

62 Tipton KD, Elliott TA, Cree MG, et al.: Ingestion of casein and whey proteins results in muscle anabolism after resistance exercise. Med Sci Sports Exerc 2004, 36(12):2073-2081.

63 Andersen LL, Tufekovic G, Zebis MK, et al.: The effect of resistance training and combined with timed ingestion of protein muscle fiber size and muscle strength. Metabolism 2005, 54(2):151-156.

64 Durham WJ, Miller SL, Yeckel CW, et al.: Leg glucose and protein metabolism during an acute bout of resistance exercise in humans. J Appl Physiol 2004, 97:1379-1386.

65 Levenhagen DK, Carr C, Carlson MG, et al.: Postexercise protein intake enhances whole-body and leg protein accretion in humans. Med Sci Sports Exerc 2002, 34(5):828-837.

66 Tarnopolsky MA, Bosman M, MacDonald JR, et al.: Postexercise protein-carbohydrate and carbohydrate supplements increase muscle glycogen in men and women. Journal of Applied Physiology 1997, 83(6):1877-1883.

67 Roy BD, Fowles JR, Hill R, et al.: Macronutrient intake and whole body protein metabolism following resistance exercise. Med Sci Sports Exerc 2000, 32(8):1412-1418.

68 Boirie Y, Dangin M, Gachon P, et al.: Slow and fast dietary proteins differently modulate postprandial protein accretion. 94 
1997, (14930-14935)

69 Dangin M, Guillet C, Garcia-Rodenas C, et al.: The rate of protein digestion affects protein gain differently during aging in humans. J Physiol 2003, 549(2):635-644.

70 Dangin M, Boirie Y, Garcia-Rodenas C, et al.: The digestion rate of protein is an independent regulating factor of postprandial protein retention. Am J Physiol Endocrinol Metab 2001, 280:E340-E348.

71 Volpi E, Ferrando AA, Yeckel CW, et al.: Exogenous amino acids stimulate net muscle protein synthesis in the elderly. J Clin Invest 1998, 101:2000-2007.

72 Paddon-Jones D, Sheffield-Moore M, Zhang X-J, et al.: Amino acid ingestion improves muscle protein synthesis in the young and elderly. American Journal of Physiology, Endocrinology and Metabolism 2004, 286:E321-E328.

73 Volpi E, Mittendorfer B, Rasmussen BB, et al.: The response of muscle protein anabolism to combined hyperaminoacidemia and glucose-induced hyperinsulinemia is impaired in the elderly. J Clin Endocrinol Metab 2000, 85:4481-4490.

74 Volpi E, Kobayashi H, Sheffield-Moore M, et al.: Essential amino acids are primarily responsible for the amino acid stimulation of muscle protein anabolism in healthy elderly adults. American Journal of Clinical Nutrition 2003, 78:250-258. 